\title{
Deep Brain Stimulation of the Rat Subthalamic Nucleus Induced Inhibition of Median Raphe Serotonergic and Dopaminergic Neurotransmission
}

\author{
Subtalamik Nükleus Derin Beyin Stimülasyonu Sonrası Suçan Median \\ Raphe Nükleusunda Serotonerjik ve Dopaminerjik İletimin Inbibisyonu
}

Ersoy KOCABICAK ${ }^{1,2 *}$, Ali JAHANSHAHI ${ }^{2 *}$, Lisa SCHONFELD ${ }^{2,3}$, Sarah-Anna HESCHAM ${ }^{2}$, Yasin TEMEL ${ }^{2}$, Sonny TAN ${ }^{4}$

${ }^{1}$ Ondokuz Mayns University, School of Medicine, Department of Neurosurgery, Samsun, Turkey

${ }^{2}$ Maastricht University Medical Center, Departments of Neuroscience and Neurosurgery, Maastricht, Netherlands

${ }^{3}$ Hasselt University, Department of Morphology, Diepenbeek, Belgium

${ }^{4}$ University Hospital RWTH Aachen, Department of Neurosurgery, Aachen, Germany

*Authors contributed equally.

Corresponding Author: Ersoy KOCABICAK / E-mail: ersoykocabicak@gmail.com

\begin{abstract}
AIM: Deep brain stimulation (DBS) of the subthalamic nucleus (STN) relieves motor dysfunction in advanced Parkinson's disease (PD). However, STN DBS treated patients can experience unpleasant and debilitating psychiatric side effects such as depression and impulsivity. The neural basis of these psychiatric effects has been linked to a dysfunction of 5-hydroxytryptamine (5-HT, serotonin) neurotransmission. STN DBS inhibited activity of 5-HT cell bodies in the dorsal raphe nucleus (DRN). Another important 5-HT source is located in the median raphe nucleus (MRN), which also contains a population of dopamine neurons. The effects of STN DBS on the MRN are unknown. Here, we test the hypothesis that STN DBS reduces 5-HT and dopaminergic function in the MRN, which may contribute to the psychiatric side effects of STN stimulation.
\end{abstract}

MATERIAL and METHODS: Bilateral STN DBS was applied in a freely moving rat model. Following STN DBS, rats were sacrificed and the brains were processed for c-Fos, 5-HT and tyrosine hydroxylase (TH) immunohistochemistry.

RESULTS: We found that STN DBS significantly lowered c-Fos expression compared to non-stimulated controls indicating reduced neuronal activity. Moreover, the mean optical density values of 5-HT and TH cells in the MRN was significantly lower compared to controls.

CONCLUSION: These results show that STN DBS inhibits 5-HT and dopamine neurotransmission in the MRN.

KEYWORDS: Subthalamic nucleus, Median raphe nucleus, Serotonin, Dopamine, Deep brain stimulation, Parkinson's disease, Psychiatric disorders

öz

AMAÇ: Illeri evre Parkinson hastalığında uygulanan subtalamik nükleus (STN) derin beyin stimülasyonu (DBS) tremor, bradikinezi ve rijidite gibi motor semptomların gerilemesini sağlar. Bununla beraber, STN DBS ile tedavi edilmiş hastalarda depresyon, duygu durum bozukluğu gibi istenmeyen bazı psikiyatrik yan etkiler oluşabilir. Bu psikiyatrik yan etkilerin nöral temelinde 5-hydroxytryptamine (5-HT, serotonin) iletimindeki değişikliklerin rol oynadığı düşünülmektedir. Dopaminerjik nöron kaynağı olarak da görev yapan median raphe nükleusu (MRN), tıpkı dorsal raphe nükleusu gibi ratlarda bir diğer serotonerjik nöron kaynağıdır. STN DBS'in rat dorsal raphe nükleusunda serotonerjik aktivite gösteren hücreleri inhibe ettiği daha önce gösterilmiştir. Fakat STN DBS'in MRN üzerinde ne gibi etki gösterdiği bilinmemektedir. Çalışmamızda STN DBS'in sıçan median raphe nükleusunda serotonin ve dopaminerjik fonksiyonları azalttığına dair hipotezimizi araştırdık.

YÖNTEM ve GEREÇLER: Bilateral STN DBS serbest hareket eden sıçan modeline uygulandı. STN DBS sonrası sıçanlar sakrifiye edildi ve beyinleri c-Fos, 5-HT ve tirozin hidroksilaz (TH) ile immünohistokimyasal olarak işlendi.

BULGULAR: STN DBS'in, stimüle edilmemiş kontrol grubuyla karşılaştııılığında c-Fos ekspresyonunu önemli oranda azalttığını tespit ettik. Ayrıca MRN içindeki 5-HT ve TH hücrelerinin ortalama optik dansite değerleri, kontrol grubuyla karşılaştırıldığında oldukça düşüktü.

SONUÇ: Bu sonuçlar, STN DBS'in median raphe nükleusunda 5-HT ve dopamin salınımını inhibe ettiğini göstermektedir.

ANAHTAR SÖZCÜKLER: Subtalamik nükleus, Median raphe nükleusu, Serotonin, Dopamin, Derin beyin stimülasyonu, Parkinson hastalığı, Psikiyatrik bozukluklar 


\section{INTRODUCTION}

Patients with advanced Parkinson's disease (PD) suffering from severe motor fluctuations and medication side effects are potential candidates for deep brain stimulation (DBS) of the subthalamic nucleus (STN). Randomized controlled trials have demonstrated sustained improvement in PD motor disability after STN DBS $(12,51)$. Despite significant motor benefits, a number of patients develop post-operative behavioral problems, including increased impulsivity, suicide and depressive symptoms $(7,17,19,24,35,45,50)$. In general psychiatry, these symptoms are associated with a dysfunctional serotonin (5-hydroxytryptamine, 5-HT) system $(10,28,37)$. Recent animal studies showed STN DBS to inhibit $5-\mathrm{HT}$ release in forebrain regions, including the striatum and hippocampus $(11,32,41)$. Moreover, STN DBS induced 5 -HT-dependent depressive-like behavior in the forced swim test $(42,44)$. This has been linked to STN DBS inhibited 5-HT neuronal activity in the midbrain dorsal raphe nucleus (DRN) $(15,44)$. However, another important population of 5-HT cell bodies is located in the median raphe nucleus (MRN) (38). The MRN also shows extensive innervation of the forebrain and has been implicated in psychiatric disorders (49). It should be noted that the MRN is a heterogenic structure not only containing $5-\mathrm{HT}$, but also dopamine cell bodies and fibers $(21,23)$. A dysfunction in both $5-\mathrm{HT}$ and dopamine neurotransmission has been implicated in the development of psychiatric symptoms. Although research on STN DBS induced changes in 5-HT neurotransmission and psychiatric behavior has mainly focused on the DRN, it is unknown whether the MRN plays a role in these effects. The effects of STN DBS on MRN function have not been investigated before and it is unknown whether STN DBS alters MRN activity. Here we test the hypothesis that STN DBS reduces 5-HT and dopaminergic function in the MRN, which may contribute to the psychiatric effects of STN stimulation.

\section{MATERIAL and METHODS}

Twenty male albino Sprague Dawley rats ( $\mathrm{n}=10$ per group; Charles River, the Netherlands) weighing $350-400 \mathrm{~g}$ were used in this study. They were housed individually in standard transparent polypropylene cages with sawdust bedding in an air-ventilated room under a 12/12 h reversed light/dark cycle (lights on 19:00h - 07:00h) with the room temperature at $20-22^{\circ} \mathrm{C}$ and a humidity of $60-70 \%$. Standard laboratory chow (Hopefarms, Woerden, the Netherlands) and water were available ad libitum. The experimental protocol was approved by the Animal Experiments and Ethics Committee of Maastricht University.

Rats underwent electrode implantation using a stereotactic frame (Stoelting, Wood Dale, USA) under general anesthesia with vaporized isoflurane. During surgery, body temperature was maintained at $37^{\circ} \mathrm{C}$ with a thermo-regulated heating blanket. Stimulation electrodes (bipolar coaxial gold-coated stimulation electrodes with platinum-iridium inner wire, shaft diameter $250 \mu \mathrm{m}$, tip diameter $50 \mu \mathrm{m}$; Technomed, Netherlands) were implanted bilaterally into the STN (coordinates from bregma: AP -3.8 mm, ML +/-2.5 mm, DV -8.0 $\mathrm{mm}$ (34)) and fixed to the skull using miniature screws and dental cement (Paladur, Heraeus Kulzer, Germany) (43).

For stimulations, each electrode was connected to a constantcurrent isolator (DLS100, World Precision Instruments, Germany) driven by a stimulus generator (DS8000, World Precision Instruments, Germany) and the following stimulation parameters were applied for one hour: $100 \mathrm{~mA}$, $130 \mathrm{~Hz}$ and $60 \mu \mathrm{s}$ pulse width, which previously inhibited 5 -HT neurotransmission and induced non-motor behavioral changes in this rat model $(15,41,43,44,46)$. Sham-stimulated rats also received bilateral STN electrode implantation. These rats were connected to the stimulator but were not stimulated. After a course of daily stimulations for 1 hour, the animals were sacrificed 2 hours after the last stimulation session. Animals were deeply anesthetized with pentobarbital $(75 \mathrm{mg} / \mathrm{kg})$ and perfused transcardially with Tyrode $\left(0.02 \% \mathrm{KCl}, 0.005 \% \mathrm{MgCl}_{2^{\prime}}\right.$ $0.8 \% \mathrm{NaCl}, 0.004 \% \mathrm{NaH}_{2} \mathrm{Po}_{4^{\prime}} 0.1 \% \mathrm{NaHco}_{3}$ and $0.1 \%$ glucose; $0.1 \mathrm{M}$ ) and fixative containing $4 \%$ paraformaldehyde, $15 \%$ picric acid and $0.05 \%$ glutaraldehyde in $0.1 \mathrm{M}$ phosphate buffer (pH 7.6). Brains were removed, post-fixed and cryoprotected with a sucrose solution before being frozen with carbon dioxide and stored at $-80^{\circ} \mathrm{C}$. Subsequently, the brains were cut serially on a cryostat into $30 \mu \mathrm{m}$ thick coronal sections.

Brain sections containing the electrode trajectories were mounted on gelatine-coated slides and processed for a standard hematoxylin-eosin staining to evaluate the location of the electrode tips. On sections containing the MRN, immunohistochemistry was carried out for c-Fos, a marker of neuronal activation, 5-HT and tyrosine hydroxylase (TH), the enzyme responsible for production of the dopamine precursor I-dopa. The sections were incubated with the following primary antibodies: rabbit anti-c-Fos (1:1000, Santa Cruz Biotechnology, Inc., USA), rabbit anti-5-HT (1:40,000 (38)) and mouse anti-TH (1:100, kindly supplied by Dr. C. Cuello, Canada). Antibodies were diluted in a $0.1 \%$ Bovine Serum Albumin (BSA) and Tris Buffered Solution (TBS)-Triton (TBS-T) solution. After three-night incubation for 5-HT and overnight incubation for TH and c-Fos, sections were incubated with the secondary antibody (donkey anti-rabbit and donkey antimouse biotine, Jackson Immunoresearch Laboratories Inc., Westgrove, USA) for $60 \mathrm{~min}$. Subsequently, all sections were incubated with an avidin-biotin-peroxidase complex (Elite ABC-kit, Vectastatin; Burlingame, USA) for 2 hours. To visualize the immune complex of horseradish peroxide reaction product, sections were exposed to a nickel chloride enhanced 3,3'-diaminobenzidine tetrahydrochloride solution. Finally, the sections were mounted, dehydrated, and coverslipped with Pertex (Histolab Products ab, Goteborg, Sweden).

To avoid variability, all sections were stained in the same session and all conditions were kept equal. After the stainings, photographs were taken with an Olympus AX70 bright field microscope connected to a digital camera (F-view; Olympus, Tokyo, Japan) with analysis software (Imaging System, Münster, Germany). Images were taken from three 
rostro-caudal anatomical levels from each rat: AP $-7.30 \mathrm{~mm}$, $-7.64 \mathrm{~mm}$ and $-8.0 \mathrm{~mm}$ from the bregma (34)). Light intensity and threshold conditions were kept identical for all sections. The investigators doing the measurements were blinded for different groups.

The number of c-Fos positive cells in the MRN was quantified in photographs taken with 10x magnification using Image $J$ software (NIH, http://rsbweb.nih.gov/ij/) at three different anatomical levels of the MRN. A cell was regarded as being positive when its intensity was significantly higher than the background as described previously (42). The expression of c-Fos positive cells was corrected for the analyzed area surface (cells $/ \mathrm{mm} 2$ ).

The amount of 5-HT and TH present in the MRN was assessed by measurement of cytoplasmatic optical densities in photographs taken at 40x magnification. The mean grey value of fifty 5 -HT-immunoreactive neurons was measured. Since the MRN contains a small population of TH cells, all observed $\mathrm{TH}$ containing cells were subjected to optical density analysis. Each cell was analyzed using Image J software and the light intensity and threshold conditions were similar for all sections. The density of pixels ranged from 0 (black) to 255 (white). For the purpose of clarity, the grey values were converted, resulting in higher values for the dark cells and lower values for the less intensely stained cells. The optical density difference of the cytoplasm compared with the mean background was taken as the outcome parameter, representing cytoplasmic 5-HT and TH content $(15,20,52)$.

All data are presented in mean \pm standard error of the mean (S.E.M.). Statistical analysis was performed with the Independent sample's t-test using SPSS 16.0 version for Windows. P-values lower than 0.05 were considered significant.

\section{RESULTS}

Bilateral STN DBS caused a significant reduction in MRN c-Fos expression compared to non-stimulated controls (STN DBS 46 \pm 4 vs controls $60 \pm 3 ; p<0.05 ;$ Figures $1 A-C)$. STN DBS caused a significant decrease in optical density measurements of MRN 5-HT and TH neurons compared to non-stimulated controls (5-HT for STN DBS $177 \pm 3$ vs controls $204 \pm 10, \mathrm{p}<0.05$, Figures $2 \mathrm{~A}-\mathrm{C}$; TH for STN DBS $206 \pm 4$ vs controls $226 \pm 6, \mathrm{p}<0.05$, Figures 2D-F). This is indicative for lowered $5-\mathrm{HT}$ and $\mathrm{TH}$ concentrations within the MRN.

The electrode tips of 4 rats from the STN DBS group were located outside the anatomical boundaries of the STN. Data from those rats were excluded from analysis. Overall there were no signs of excessive tissue damage due to surgery or stimulation, including intracranial hemorrhage or ischemia (Figure 3).

\section{DISCUSSION}

STN DBS has become a popular neurosurgical therapy in advanced PD. However, suicides are more frequent postoperatively and depressive symptoms negatively influence the quality of life $(47,50)$. Therefore, psychiatric side effects are an important issue and require understanding of their underlying mechanisms. Psychiatric symptoms are generally linked to a dysfunctional 5-HT system $(10,28,37)$. Recent rat studies have shown STN DBS to induce 5-HT-dependent depressive-like behavior in the forced swim test $(42,44)$. Moreover, STN DBS decreased $5-\mathrm{HT}$ release measured by in vivo microdialysis in forebrain regions, including the prefrontal cortex, striatum und hippocampus (11, 32, 41). Extracellular single cell recordings demonstrated STN DBS to inhibit 5-HT neuronal firing in the DRN, the largest source of 5 -HT cell bodies in the central nervous system $(15,44)$. Another important 5-HT population is located in the MRN. Both DRN and MRN are implicated in psychiatric disorders but have distinct forebrain innervation patterns (16). However, the effect of STN DBS on MRN neurotransmission is unknown.

In the present study, we found a significant decrease in MRN c-Fos expression after STN DBS compared to non-stimulated controls. This indicates a decrease in local neuronal activity.

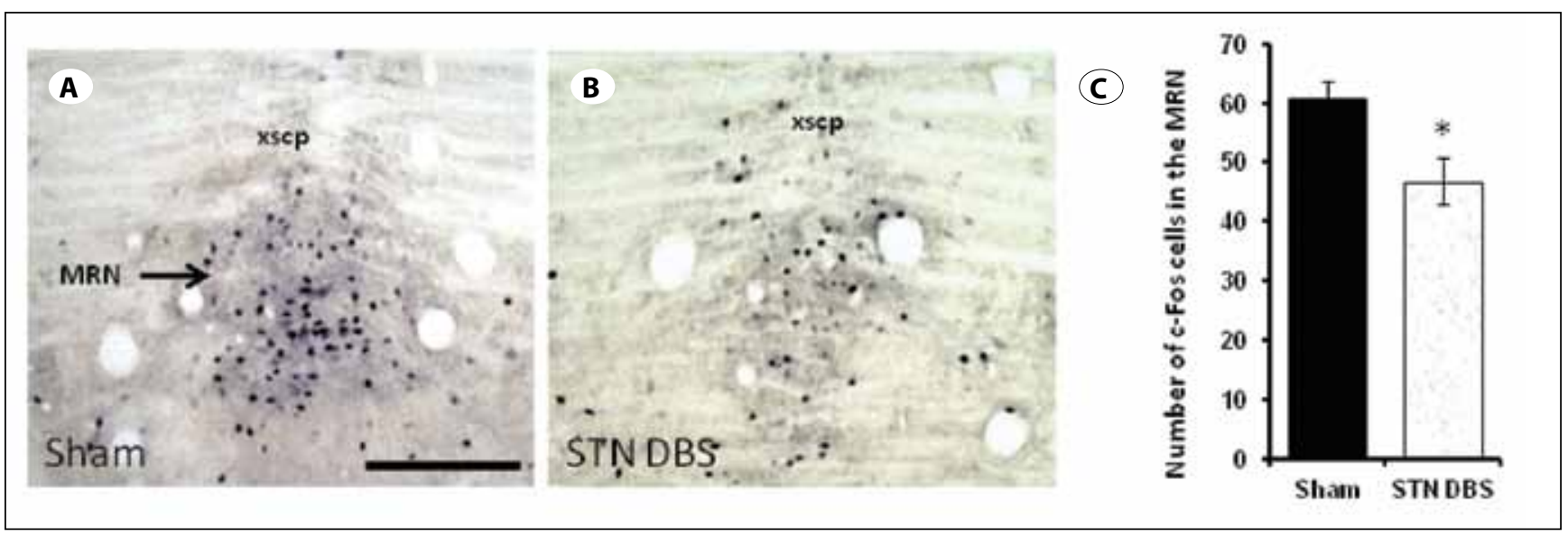

Figure 1: Representative low-power photomicrographs of c-Fos expression in the median raphe nucleus (MRN) of a sham (A) and STN DBS rat (B). Cumulative data of c-Fos expression in the MRN, expressed as the number of c-Fos positive cells per $\mathrm{mm}^{2}$ ( $\mathrm{mean}^{ \pm} \mathrm{s} . \mathrm{e} . \mathrm{m}$.; STN DBS vs sham, $\left.{ }^{*} p<0.05\right)$ (C). $x s c p$, decussation of the superior cerebellar peduncle; Scale bar: $200 \mu \mathrm{m}$. 


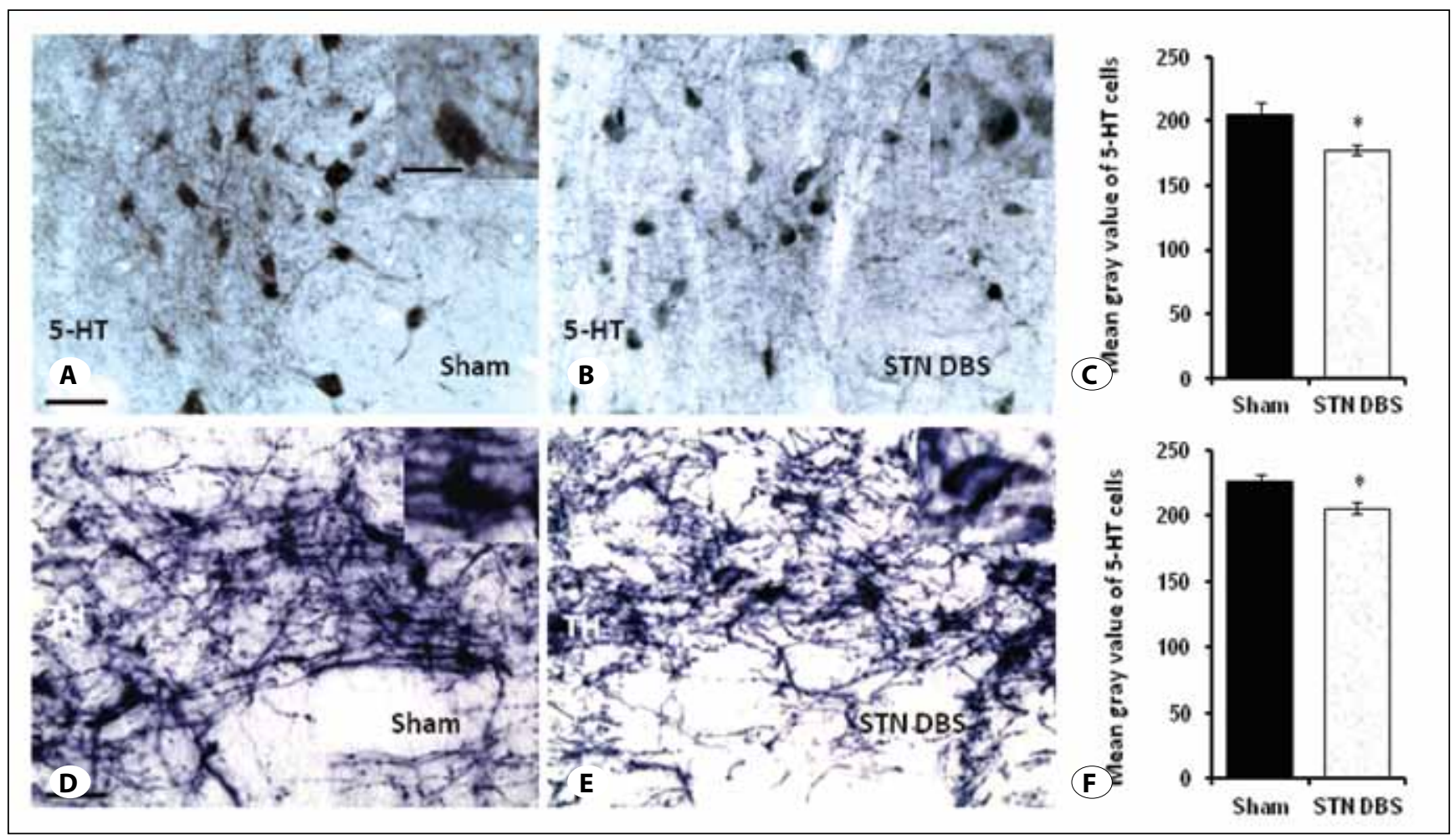

Figure 2: The figures represent high-power photomicrographs (40 $\mathrm{x}$ ) of a $30 \mu \mathrm{m}$-think section from the MRN of animals treated with DBS in the STN. A, B) 5-HT containing cells in the MRN of a sham, and STN DBS rat. D, E) TH containing cells in the MRN of a sham, and STN DBS rat. The graphs ( $\mathbf{C}$ and F) represent the means \pm S.E.M. of mean grey value of 5-HT and TH positive cells. Note that DBS induced a remarkable reduction of optical density of 5-HT and TH containing cells. ${ }^{*}$ indicates significant difference as compared with sham animals $(P<0.05)$. Scale bar: $50 \mu \mathrm{m}$.

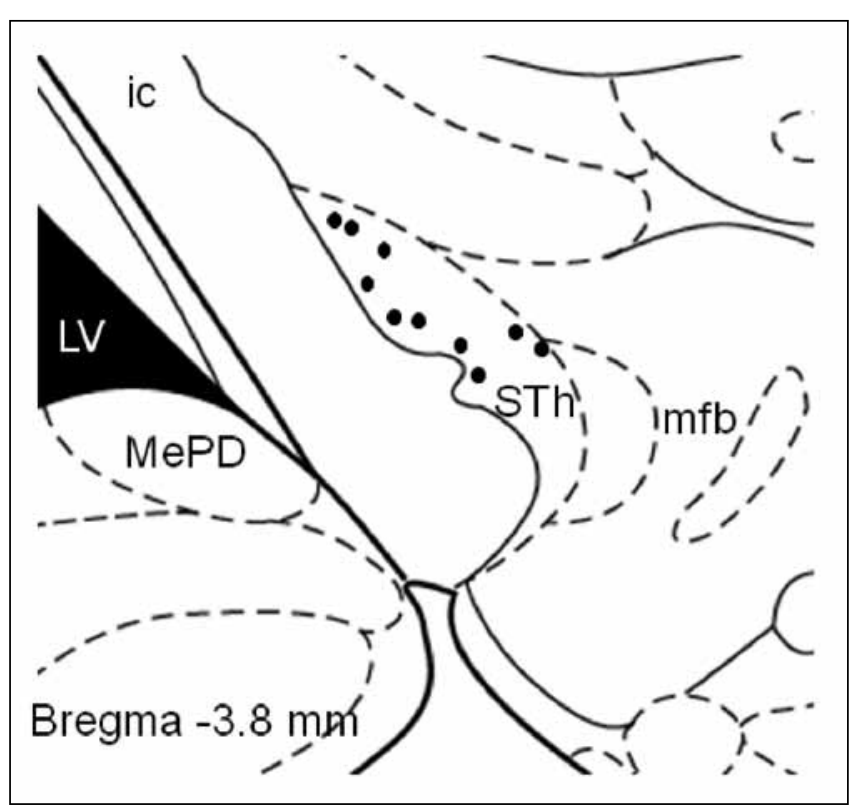

Figure 3: Schematic representation of the midbrain in rat (23), showing the localization of the electrode tips in the subthalamic nucleus (STh). Medial forebrain bundle ( $\mathbf{m f b})$, internal capsule (ic), medial amygdaloid nucleus (MePD) and lateral ventricle (LV).
In line with other STN DBS experiments a baseline c-Fos expression was expected in non-stimulated controls and was demonstrated earlier in regions including the DRN, lateral habenula and cerebellar nuclei $(30,42)$. The decreased MRN activity after STN DBS was anticipated based on 5-HT microdialysis experiments in rats showing decreased 5-HT release in the ventral hippocampus after STN DBS (32). The ventral hippocampus receives $5-\mathrm{HT}$ innervation from both the DRN and MRN (29).

Recently, we also found a change in c-Fos expression in the DRN after STN DBS. Interestingly, stimulation caused a significant increase in DRN c-Fos expression in particular in the lateral DRN (42). The lateral DRN contains GABA interneurons important in inhibitory control of DRN 5-HT neurons $(2,48)$. These may be important in STN DBS induced decrease in neuronal activity of DRN 5-HT neurons $(15,44)$. Moreover, the MRN and DRN are interconnected with many bidirectional projections. Inhibition of DRN activity by STN DBS is likely to result in altered MRN activity as well.

We also found 5-HT density of MRN neurons to decrease significantly after STN DBS compared to non-stimulated controls, which reflects a decrease in MRN 5-HT concentration. Altered MRN 5-HT neurotransmission has been associated with mood disorders $(3,25)$. It is estimated that only circa $35 \%$ 
of the MRN are 5-HT-containing neurons (27). The remaining include dopamine producing cell bodies among others (21). In our rat model STN DBS caused a decrease in MRN TH neuronal density. This suggests a STN DBS induced decrease in MRN dopamine concentration. We have also observed the presence of many TH-positive fibers in the MRN. This is in line with a previous study demonstrating the MRN to contain abundant dopamine-immunoreactive fibers (23). However, these fibers may originate outside the MRN in the ventral tegmental area or substantia nigra, which are important MRN afferents (4). STN DBS has demonstrated to increase neuronal activity of dopamine neurons in the substantia nigra pars compacta (5, 26). Some studies found increased striatal dopamine release in animal models, whereas clinical imaging studies did not support this observation $(1,8,18)$. The effect of STN DBS on ventral tegmental dopamine neurons is unknown.

However, it should be kept in mind that the TH positive neurons and fibers may also represent other catecholamines. For example, noradrenaline terminals have been demonstrated in the $\operatorname{MRN}(33,36)$. A staining for aromatic L-amino acid decarboxylase (AADC) would provide additional information for neuronal elements converting L-3,4-dihydroxyphenylalanine (L-dopa) into dopamine.

Anatomical tracing studies have not shown projections from the STN to the MRN or vice versa $(4,9,49)$. Most likely it involves a multisynaptic pathway. Major STN projection targets, such as the ventral pallidum and substantia nigra, are important MRN afferents $(4,13,22)$. The substantia nigra receives major STN input (14). Electrophysiological studies have demonstrated a decreased activity of substantia nigra pars reticulata neurons by STN DBS $(6,40)$. The ventral pallidum is connected to the medial STN, which is considered limbic subregion of the STN. However, the effects of STN DBS on the ventral pallidum are unknown. Moreover, another major MRN afferent originates in the lateral habenula (4). Although the STN does not directly project to the lateral habenula, we recently demonstrated STN stimulation induced activation of this region (42). The lateral habenula has been implicated in the regulation of both 5-HT and dopamine neurotransmission. In addition, hyperactivity of this structure has been associated with depression $(31,39)$. Therefore, one or more of these structures may mediate the inhibitory effect of STN DBS on MRN neurotransmission.

\section{CONCLUSION}

In this study, we have demonstrated that STN DBS decreased MRN neuronal activity. In addition, STN DBS reduced neuronal levels of $5-\mathrm{HT}$ and $\mathrm{TH}$ in the MRN, suggesting a potential contribution of this region to the development of STN DBSrelated behavioral side effects.

\section{REFERENCES}

1. Abosch A, Kapur S, Lang AE, Hussey D, Sime E, Miyasaki J, Houle S, Lozano AM: Stimulation of the subthalamic nucleus in Parkinson's disease does not produce striatal dopamine release. Neurosurgery 53:1095-1102; discussion 102-105,2003
2. Allers KA, Sharp T: Neurochemical and anatomical identification of fast- and slow-firing neurones in the rat dorsal raphe nucleus using juxtacellular labelling methods in vivo. Neuroscience 122:193-204,2003

3. Bach-Mizrachi $\mathrm{H}$, Underwood MD, Tin A, Ellis SP, Mann JJ, Arango V: Elevated expression of tryptophan hydroxylase-2 mRNA at the neuronal level in the dorsal and median raphe nuclei of depressed suicides. Mol Psychiatry 13:507-513, 465, 2008

4. Behzadi G, Kalen P, Parvopassu F, Wiklund L: Afferents to the median raphe nucleus of the rat: Retrograde cholera toxin and wheat germ conjugated horseradish peroxidase tracing, and selective $\mathrm{D}-[3 \mathrm{H}]$ aspartate labelling of possible excitatory amino acid inputs. Neuroscience 37:77-100,1990

5. Benazzouz A, Gao D, Ni Z, Benabid AL: High frequency stimulation of the STN influences the activity of dopamine neurons in the rat. Neuroreport 11:1593-1596,2000

6. Benazzouz A, Piallat B, Pollak P, Benabid AL: Responses of substantia nigra pars reticulata and globus pallidus complex to high frequency stimulation of the subthalamic nucleus in rats: Electrophysiological data. Neurosci Lett 189:77-80,1995

7. Berney A, Vingerhoets F, Perrin A, Guex P, Villemure JG, Burkhard PR, Benkelfat C, Ghika J: Effect on mood of subthalamic DBS for Parkinson's disease: A consecutive series of 24 patients. Neurology 59:1427-1429,2002

8. Bruet N, Windels F, Bertrand A, Feuerstein C, Poupard A, Savasta M: High frequency stimulation of the subthalamic nucleus increases the extracellular contents of striatal dopamine in normal and partially dopaminergic denervated rats. J Neuropathol Exp Neurol 60:15-24,2001

9. Canteras NS, Shammah-Lagnado SJ, Silva BA, Ricardo JA: Afferent connections of the subthalamic nucleus: A combined retrograde and anterograde horseradish peroxidase study in the rat. Brain Res 513:43-59,1990

10. Cowen PJ: Serotonin and depression: Pathophysiological mechanism or marketing myth? Trends Pharmacol Sci 29: 433-436,2008

11. Creed MC, Hamani C, Bridgman A, Fletcher PJ, Nobrega $\mathrm{JN}$ : Contribution of decreased serotonin release to the antidyskinetic effects of deep brain stimulation in a rodent model of tardive dyskinesia: Comparison of the subthalamic and entopeduncular nuclei. J Neurosci 32:9574-9581,2012

12. Deuschl G, Schade-Brittinger $C$, Krack P, Volkmann J, Schäfer $H$, Bötzel K, Daniels $C$, Deutschländer A, Dillmann U, Eisner W, Gruber D, Hamel W, Herzog J, Hilker R, Klebe S, Kloss M, Koy J, Krause M, Kupsch A, Lorenz D, Lorenzl S, Mehdorn HM, Moringlane JR, Oertel W, Pinsker MO, Reichmann H, Reuss A, Schneider GH, Schnitzler A, Steude U, Sturm V, Timmermann L, Tronnier V, Trottenberg T, Wojtecki L, Wolf E, Poewe W, Voges J; German Parkinson Study Group, Neurostimulation Section. A randomized trial of deep-brain stimulation for Parkinson's disease. N Engl J Med 355:896-908, 2006

13. Groenewegen HJ, Berendse HW: Connections of the subthalamic nucleus with ventral striatopallidal parts of the basal ganglia in the rat. J Comp Neurol 294:607-622,1990 
14. Hammond C, ShibazakiT, Rouzaire-Dubois B: Branched output neurons of the rat subthalamic nucleus: Electrophysiological study of the synaptic effects on identified cells in the two main target nuclei, the entopeduncular nucleus and the substantia nigra. Neuroscience 9:511-520,1983

15. Hartung H, Tan SK, Steinbusch HM, Temel Y, Sharp T: Highfrequency stimulation of the subthalamic nucleus inhibits the firing of juxtacellular labelled 5-HT-containing neurones. Neuroscience 186:135-145,2011

16. Hensler JG: Serotonergic modulation of the limbic system. Neurosci Biobehav Rev 30:203-214,2006

17. Herzog J, Reiff J, Krack P, Witt K, Schrader B, Müller D, Deuschl $\mathrm{G}$ : Manic episode with psychotic symptoms induced by subthalamic nucleus stimulation in a patient with Parkinson's disease. Mov Disord 18:1382-1384, 2003

18. Hilker R, Voges J, Ghaemi M, Lehrke R, Rudolf J, Koulousakis A, Herholz K, Wienhard K, Sturm V, Heiss WD: Deep brain stimulation of the subthalamic nucleus does not increase the striatal dopamine concentration in parkinsonian humans. Mov Disord 18:41-48,2003

19. Houeto JL, Damier P, Bejjani PB, Staedler C, Bonnet AM, Arnulf I, Pidoux B, Dormont D, Cornu P, Agid Y: Subthalamic stimulation in Parkinson disease: A multidisciplinary approach. Arch Neurol 57:461-465, 2000

20. Jahanshahi A, Lim LW, Steinbusch HW, Visser-Vandewalle V, Temel Y: Buspirone-induced changes in the serotonergic and non-serotonergic cells in the dorsal raphe nucleus of rats. Neurosci Lett 473:136-140,2010

21. Jahanshahi A, Steinbusch HW, Temel Y: Distribution of dopaminergic cell bodies in the median raphe nucleus of the rat brain. J Chem Neuroanat 53:60-63,2013

22. Kita $H$, Kitai ST: Efferent projections of the subthalamic nucleus in the rat: Light and electron microscopic analysis with the PHA-L method. J Comp Neurol 260:435-452,1987

23. Kitahama K, Nagatsu I, Geffard M, Maeda T: Distribution of dopamine-immunoreactive fibers in the rat brainstem. J Chem Neuroanat 18:1-9,2000

24. Kulisevsky J, Berthier ML, Gironell A, Pascual-Sedano B, Molet J, Pares P: Mania following deep brain stimulation for Parkinson's disease. Neurology 59:1421-1424, 2002

25. Lanzenberger R, Kranz GS, Haeusler D, Akimova E, Savli M, Hahn A, Mitterhauser M, Spindelegger C, Philippe C, Fink M, Wadsak W, Karanikas G, Kasper S: Prediction of SSRI treatment response in major depression based on serotonin transporter interplay between median raphe nucleus and projection areas. Neuroimage 63:874-881,2012

26. Lee KH, Chang SY, Roberts DW, Kim U: Neurotransmitter release from high-frequency stimulation of the subthalamic nucleus. J Neurosurg 101:511-517,2004

27. Leger L, Wiklund L: Distribution and numbers of indoleamine cell bodies in the cat brainstem determined with Falck-Hillarp fluorescence histochemistry. Brain Res Bull 9:245-251,1982

28. Mann JJ: Neurobiology of suicidal behaviour. Nat Rev Neurosci 4:819-828,2003
29. McQuade R, Sharp T: Release of cerebral 5-hydroxytryptamine evoked by electrical stimulation of the dorsal and median raphe nuclei: Effect of a neurotoxic amphetamine. Neuroscience 68:1079-1088,1995

30. Moers-Hornikx VM, Vles JS, Tan SK, Cox K, Hoogland G, Steinbusch WM, Temel Y: Cerebellar nuclei are activated by high-frequency stimulation of the subthalamic nucleus. Neurosci Lett 496:111-115,2011

31. Morris JS, Smith KA, Cowen PJ, Friston KJ, Dolan RJ: Covariation of activity in habenula and dorsal raphe nuclei following tryptophan depletion. Neuroimage 10:163-172,1999

32. Navailles S, Benazzouz A, Bioulac B, Gross C, De Deurwaerdere $P$ : High-frequency stimulation of the subthalamic nucleus and L-3,4-dihydroxyphenylalanine inhibit in vivo serotonin release in the prefrontal cortex and hippocampus in a rat model of Parkinson's disease. J Neurosci 30:2356-2364,2010

33. Ordway GA, Stockmeier CA, Cason GW, Klimek V: Pharmacology and distribution of norepinephrine transporters in the human locus coeruleus and raphe nuclei. J Neurosci 17: 1710-1719,1997

34. Paxinos G, Watson C: The Rat Brain in Stereotaxic Coordinates. 4th ed. San Diego: Academic Press, 1998

35. Piasecki SD, Jefferson JW: Psychiatric complications of deep brain stimulation for Parkinson's disease. J Clin Psychiatry 65:845-849,2004

36. Smith HR, Beveridge TJ, Porrino LJ: Distribution of norepinephrine transporters in the non-human primate brain. Neuroscience 138:703-714,2006

37. Smith KA, Fairburn CG, Cowen PJ: Relapse of depression after rapid depletion of tryptophan. Lancet 349:915-919,1997

38. Steinbusch HW: Distribution of serotonin-immunoreactivity in the central nervous system of the rat-cell bodies and terminals. Neuroscience 6:557-618,1981

39. Tai $\mathrm{CH}$, Boraud T, Bezard E, Bioulac B, Gross C, Benazzouz A: Cerebral correlates of depressed behavior in rats, visualized using 14C-2-deoxyglucose autoradiography. J Neurosci 8:1951-1961,1988

40. Tai $\mathrm{CH}$, Boraud T, Bezard E, et al: Electrophysiological and metabolic evidence that high-frequency stimulation of the subthalamic nucleus bridles neuronal activity in the subthalamic nucleus and the substantia nigra reticulata. FASEB J 17:1820-1830, 2003

41. Tan SK, Hartung $H$, Visser-Vandewalle V, Steinbusch HW, Temel Y, Sharp T: A combined in vivo neurochemical and electrophysiological analysis of the effect of high-frequency stimulation of the subthalamic nucleus on 5-HT transmission. Exp Neurol 233:145-153,2012

42. Tan SK, Janssen ML, Jahanshahi A, Chouliaras L, VisserVandewalle V, Lim LW, Steinbusch HW, Sharp T, Temel Y: High frequency stimulation of the subthalamic nucleus increases c-fos immunoreactivity in the dorsal raphe nucleus and afferent brain regions. J Psychiatr Res 45:1307-1315,2011

43. Tan S, Vlamings $R$, Lim L, Sesia T, Janssen ML, Steinbusch HW, Visser-Vandewalle V, Temel Y: Experimental deep brain stimulation in animal models. Neurosurgery 67:1073-1079; discussion 80, 2010 
44. Temel Y, Boothman LJ, Blokland A, Magill PJ, Steinbusch HW, Visser-Vandewalle V, Sharp T: Inhibition of 5-HT neuron activity and induction of depressive-like behavior by highfrequency stimulation of the subthalamic nucleus. Proc Natl Acad Sci U S A 104:17087-17092,2007

45. Temel Y, Kessels A, Tan S, Topdag A, Boon P, Visser-Vandewalle $\mathrm{V}$ : Behavioural changes after bilateral subthalamic stimulation in advanced Parkinson disease: A systematic review. Parkinsonism Relat Disord 12:265-272,2006

46. Temel $Y$, Visser-Vandewalle V, Aendekerk B, Rutten B, Tan S, Scholtissen B, Schmitz C, Blokland A, Steinbusch HW: Acute and separate modulation of motor and cognitive performance in parkinsonian rats by bilateral stimulation of the subthalamic nucleus. Exp Neurol 193:43-52,2005

47. Troster Al, Fields JA, Wilkinson S, Pahwa R, Koller WC, Lyons KE: Effect of motor improvement on quality of life following subthalamic stimulation is mediated by changes in depressive symptomatology. Stereotact Funct Neurosurg 80:43-47,2003

48. Varga V, Kocsis B, Sharp T: Electrophysiological evidence for convergence of inputs from the medial prefrontal cortex and lateral habenula on single neurons in the dorsal raphe nucleus. Eur J Neurosci 17:280-286,2003
49. Vertes RP, Fortin WJ, Crane AM: Projections of the median raphe nucleus in the rat. J Comp Neurol 407:555-582,1999

50. Voon V, Krack P, Lang AE, Lozano AM, Dujardin K, Schupbach M, D'Ambrosia J, Thobois S, Tamma F, Herzog J, Speelman JD, Samanta J, Kubu C, Rossignol H, Poon YY, Saint-Cyr JA, Ardouin C, Moro E: A multicentre study on suicide outcomes following subthalamic stimulation for Parkinson's disease. Brain 131:2720-2728,2008

51. Weaver FM, Follett K, Stern M, Hur K, Harris C, Marks WJ Jr, Rothlind J, Sagher O, Reda D, Moy CS, Pahwa R, Burchiel K, Hogarth P, Lai EC, Duda JE, Holloway K, Samii A, Horn S, Bronstein J, Stoner G, Heemskerk J, Huang GD; CSP 468 Study Group: Bilateral deep brain stimulation vs best medical therapy for patients with advanced Parkinson disease: A randomized controlled trial. JAMA 301:63-73, 2009

52. Yakkioui $Y$, Temel $Y$, Creytens $D$, Jahanshahi $A$, Fleischeuer $R$, Santegoeds RG, Van Overbeeke JJ: A comparison of cell-cycle markers in skull base and sacral chordomas. World Neurosurg 82(1-2):e311-318, 2014 